\title{
PENGARUH PENGELASAN TIG FILLER ER 4043 DAN POST-WELD HEAT TREATMENT ALUMINIUM PADUAN TERHADAP SIFAT MEKANIK DAN STRUKTUR MIKRO
}

\author{
*Gunawan Dwi Haryadi, Himawan Kristian Kustomo \\ Jurusan Teknik Mesin, Fakultas Teknik, Universitas Diponegoro \\ J1. Prof. Sudharto, SH., Tembalang-Semarang 50275, Telp. +62247460059 \\ *E-mail: gunawan_dh@yahoo.com
}

\begin{abstract}
ABSTRAK
Aluminium paduan di dunia industri pada saat ini terus berkembang pesat karena aluminium memiliki sifat mekanik yang baik, seperti tahan korosi, bobot yang ringan, kekuatan dan kekerasan yang tinggi, serta mampu di daur ulang.Pengelasan merupakan salah satu penyebab terjadinya kegagalan pada sebagian besar komponen di dunia industri. Tujuan dari penelitian ini adalah untuk mengetahui kekuatan tarik, kekerasan dan struktur mikro dari Aluminium Alloy 6061-O dengan arah pengelasan tungsten inert gas (TIG) longitudinal yang di-post weld heat treatment (PWHT) ataupun yang tidak di PWHT, kemudian menyimpulkan hasil perubahan sifat mekanik dari material uji. Penenlitian ini menggunakan perlakuan panas T6 dengan temperatur solution $520^{\circ} \mathrm{C}$ dan quenching air dingin, kemudian artificial aging dengan temperatur $175^{\circ} \mathrm{C}$ dan variasi waktu selama 8 jam, 18 jam, dan 24 jam. Hasil dari penelitian ini menunjukkan kekuatan tarik material mengalami peningkatan setelah diPWHT dengan kekuatan tarik tertinggi yaitu PWHT 24 jam sebesar $389.492 \mathrm{MPa}$, ini lebih besar dari material PWHT 18 jam yaitu 378.021 MPa dan PWHT 8 Jam yaitu 365.294 MPa. Adanya penurunan regangan pada material yang telah di-PWHT 8 jam, 18 jam, dan 24 jam masing-masing sebesar 5.9\%, $2.4 \%$, dan $3.2 \%$. Nilai kekerasan mengalami peningkatan setelah di-PWHT. PWHT selama 8 jam memiliki nilai kekerasan tertinggi pada daerah heat affected zone (HAZ) yaitu sebesar 109.7 Hv. Sedangkan material pengelasan tanpa PWHT dan PWHT 8 jam dan 24 jam masing-masing hanya memiliki nilai kekerasan tertinggi $81.4 \mathrm{Hv}, 100.2 \mathrm{Hv}$, dan 104.7 Hv. Dari hasil pengamatan struktur mikro terlihat adanya perbedaan struktur butir, material tanpa PWHT memiliki ukuran butir yang lebih besar dari material yang di-PWHT. Proses PWHT meningkatkan kekuatan tarik dan nilai kekerasan, tetapi menurunkan sifat elastis dari material. Material PWHT 8 jam memiliki sifat mampu bentuk yang paling baik, sedangkan kekuatan material tertinggi yaitu PWHT selama 24 jam.
\end{abstract}

Kata kunci: aging, aluminium alloy 6061-O, las TIG,post weld heat treatment, sifat mekanik

\section{PENDAHULUAN}

Di dunia industri otomotif seperti rangka kapal, perpipaan, dan industri pesawat terbang material jenis aluminium paduan 6061 banyak digunakan. Tipe alumium ini mengandung magnesium (Mg) dan silika (Si) sebagai elemen paduan utama [1].

Saat ini pengelasan TIG merupakan salah satu metode yang sering digunakan, tidak hanya dapat mengelas semua logam untuk keperluan industri, tetapi juga dapat menghasilkan kualitas las lebih baik dibanding las gas [2].

Secara umum, struktur yang dilas memiliki sifat mekanik yang kurang baik daripada logam dasarnya. Pada daerah pengelasan (WM) dan daerah terpengaruh panas (HAZ) memiliki dampak energi yang lebih rendah dan keuletan yang rendah daripada logam dasar (BM). [3]. Untuk mengatasi masalah tersebut material yang telah dilas dilakukan perlakuan panas, yaitu untuk meningkatkan sifat mekanik dan juga mengurangi tegangan sisa. Perlakuan panas untuk alumunium dilakukan dengan solution heat treatment, diikuti dengan quenching, dan aging, untuk temperatur tertentu dengan pendinginan natural di udara [4].

Tujuan dari penelitian ini adalah untuk mengevaluasi efek dari post welding heat treatment (PWHT) dan arah pengelasan TIG yaitu longitudinal terhadap arah pengerolan material pada alumunium paduan 6061-O dengan temperatur tertentu dan berbagai waktu aging, kemudian membandingkan hasil yang di dapat dengan alumunium paduan 6061 tanpa dilakukan PWHT terhadap sifat mekanik dan struktur mikronya.

\section{MATERIAL DAN METODOLOGI}

Material yang digunakan yaitu plat aluminium paduan 6061-O dengan tebal $1.6 \mathrm{~mm}$. Untuk lebih jelas lihat pada Gambar 1.Untuk komposisi kimia dapat dilihat pada Tabel 1. Aluminium ini pada umumnya digunakan pada industri pesawat terbang 


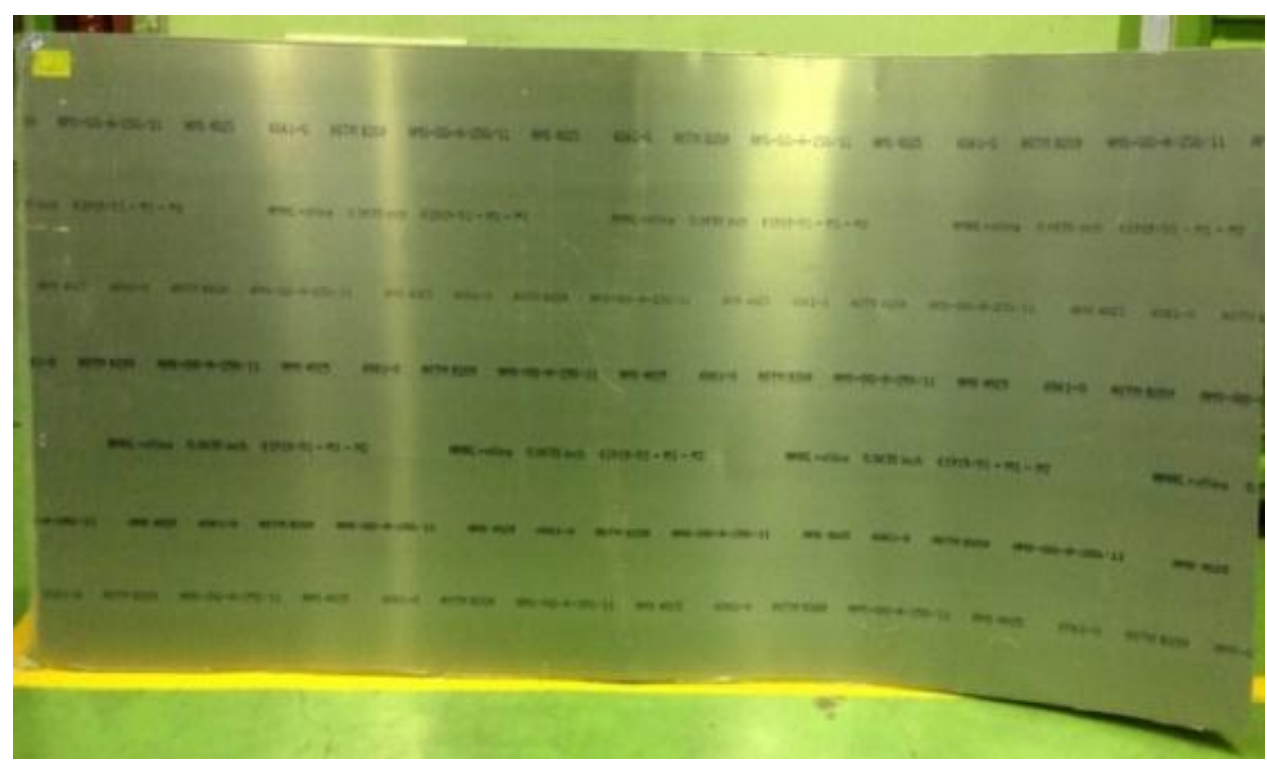

Gambar 1. Plat aluminium paduan 6061-O

Tabel 1. Komposisi kimia AA 6061-O (Wt\%)

\begin{tabular}{|c|c|c|c|c|c|c|c|c|c|c|}
\hline Material & $\mathrm{Al}$ & $\mathrm{Si}$ & $\mathrm{Fe}$ & $\mathrm{Cu}$ & $\mathrm{Mn}$ & $\mathrm{Mg}$ & $\mathrm{Cr}$ & $\mathrm{Zn}$ & $\mathrm{Ti}$ & Lainnya \\
\hline AA 6061-O & 97,32 & 0,69 & 0,5 & 0,22 & 0,11 & 0,86 & 0,15 & 0,11 & 0,05 & 0,02 \\
\hline
\end{tabular}

Proses pengelasan spesimen menggunakan ER 4043 dengan komposisi kimia dapat dilihat pada Tabel 2. Arah pengelasan longitudinal terhadap arah pengerolan.Pengelasan menggunakan las Tungsten Inert Gas (TIG) dengan parameter pengelasan dapat dilihat pada Tabel 3 .

Tabel 2. Komposisi kimia filler ER 4043 (Wt\%)

\begin{tabular}{|c|c|c|c|c|c|c|c|c|c|c|}
\hline Material & $\mathrm{Al}$ & $\mathrm{Si}$ & $\mathrm{Fe}$ & $\mathrm{Cu}$ & $\mathrm{Mn}$ & $\mathrm{Mg}$ & $\mathrm{Cr}$ & $\mathrm{Zn}$ & $\mathrm{Ti}$ & Lainnya \\
\hline ER 4043 & $\mathrm{Bal}$ & 4,8 & 0,2 & 0,02 & $<0,01$ & 0,01 & - & 0,02 & 0,01 & $<0,15$ \\
\hline
\end{tabular}

Tabel 3. Parameter pengelasan TIG

\begin{tabular}{c|c}
\hline Parameter & Nilai \\
\hline Welding machine & Miller \\
Tungsten electroda diameter & $1,6 \mathrm{~mm}$ \\
Filler rod / wire diameter & $2,4 \mathrm{~mm}$ \\
Heat input & $2,5 \mathrm{~kJ} / \mathrm{mm}$ \\
Peak current & $70 \mathrm{Amps}$ \\
Base current & $60 \mathrm{Amps}$ \\
Peak voltage & $14,3 \mathrm{Volts}$ \\
Base voltage & $13,8 \mathrm{Volts}$ \\
Welding speed & $4,19 \mathrm{~mm} / \mathrm{sec}$ \\
Welding grade & $99,99 \%$ \\
Melting point & $543^{0} \mathrm{C}-640^{\circ} \mathrm{C}$ \\
Pulse frequency & $6 \mathrm{~Hz}$ \\
Pulse on time & $50 \%$ \\
Shielding gas & Argon \\
Gas flow rate & $15 \mathrm{~L} / \mathrm{min}$ \\
\hline
\end{tabular}

Dalam penelitian ini spesimen yang digunakan untuk pengujian adalah logam induk Al 6061-O, pengelasan material dengan atau tanpa perlakuan panas. Sebelum dilakukan pengujian, material diberi perlakuan panas T6. Dengan temperatur solution $520^{\circ} \mathrm{C}$ selama $1 \mathrm{jam}$, kemudian di quench air dingin. Setelah itu dilakukan artificial aging dengan temperatur $175^{\circ} \mathrm{C}$ selama 8 jam, 18 jam, dan 24 jam.Spesimen tersebut kemudian dilakukan tiga pengujian, yaitu uji tarik, uji kekerasan dan uji struktur mikro untuk lebih jelasnya dapat dilihat pada Gambar 2. 


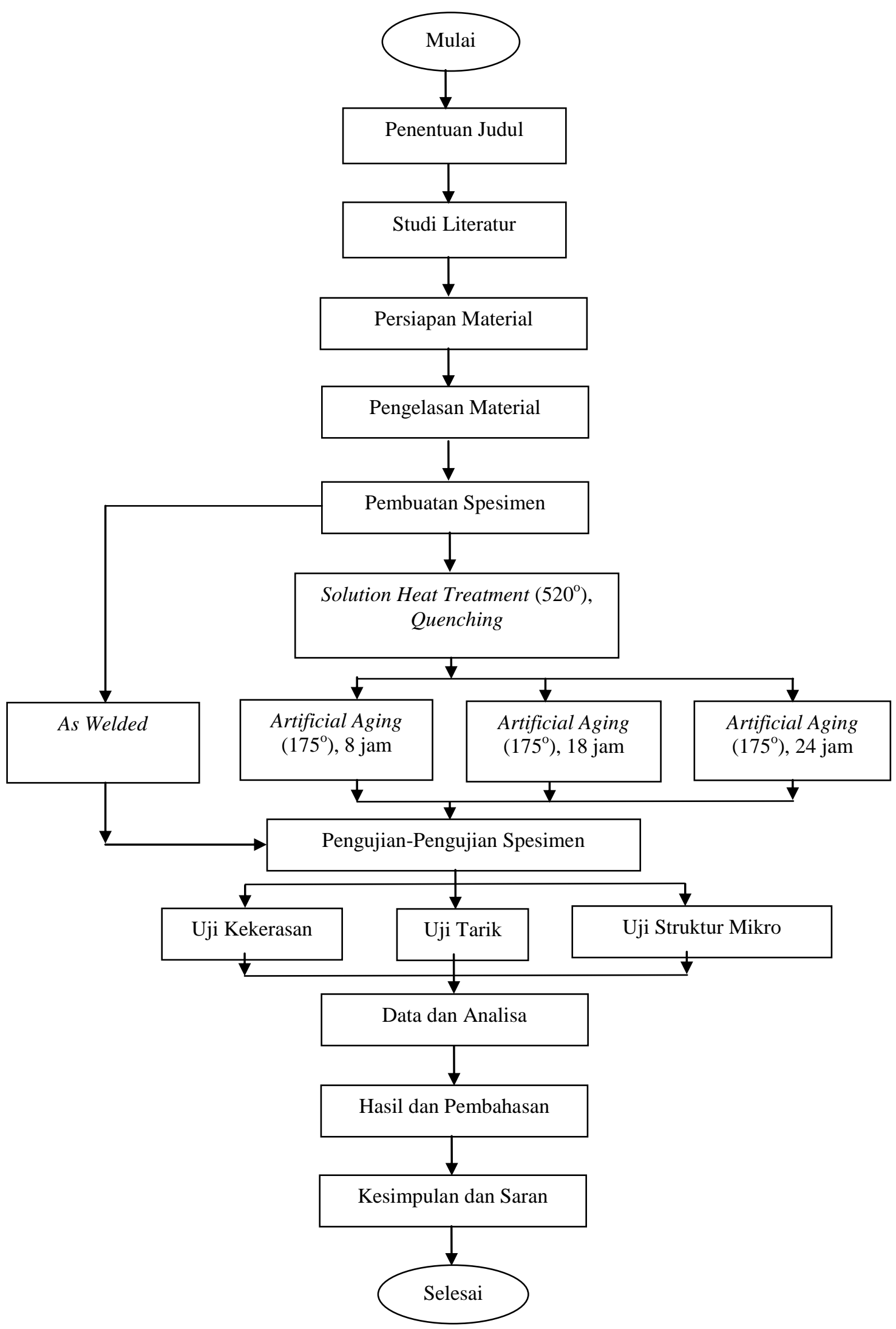

Gambar 2. Diagram alir penelitian

Pengujian tarik dibuat berdasarkan ASTM B-557-06 (American Standard Testing Materials) dimensi gambar spesimen dapat dilihat pada Gambar 3. Pengujian tarik menggunakan alat uji tarik Contolab/TN 20 MD dan dilakukan di Laboratorium Bahan Teknik Universitas Gajah Mada. 


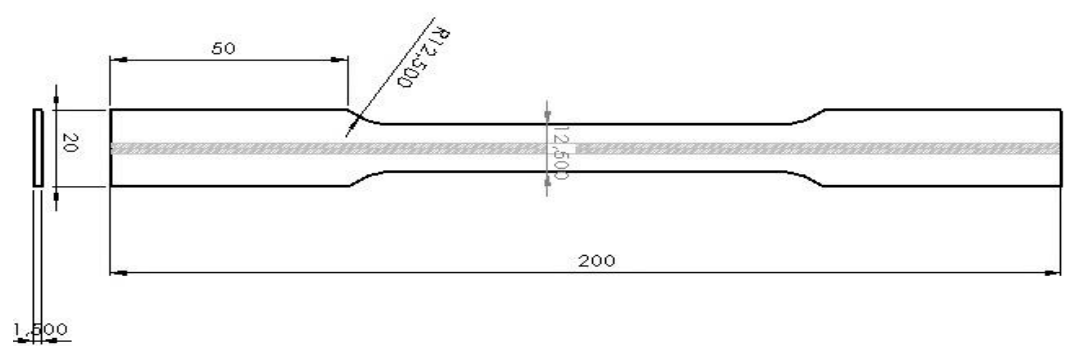

Gambar 3. Spesimen uji tarik (Standar ASTM B-557-06)

Untuk pengujian kekerasan dilakukan pada daerah logam induk (BM), daerah terpengaruh panas (HAZ), logam las (WM) dengan jarak indentasi $1 \mathrm{~mm}$, untuk lebih jelasnya bisa dilihat pada Gambar 4. Pengujian kekerasan menggunakan standar ASTM E384 dengan waktu penekanan selama 12 detik dan beban mayur 0,3 KgF. Alat uji kekerasan menggunakan mikro Vickers HM-200 Mitutoyodan dilakukan di UPT Laboratorium Terpadu Universitas Diponegoro.

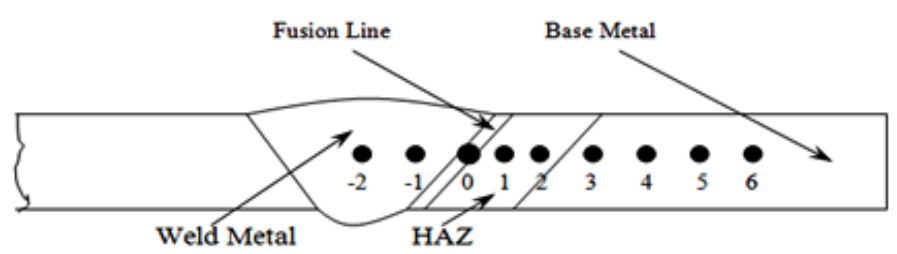

Gambar 4. Distribusi kekerasan pada daerah pengelasan

\section{HASIL DAN PEMBAHASAN}

\subsection{Hasil Pengujian Tarik}

Dari pengujian tarik yang telah dilakukan kita mendapatkan data tegangan luluh $\left(\sigma_{\mathrm{y}}\right)$, tegangan maksimum $\left(\sigma_{\mathrm{u}}\right)$,dan regangan $(\varepsilon)$ dari logam induk aluminium, as welded, PWHT 8 jam, PWHT 18 jam dan PWHT 24 jam. Spesimen pengujian tarik menggunakan standar ASTM B 557-06.Hasil pengujian tarik dapat ditunjukkan pada Gambar 5 dan Gambar 6.

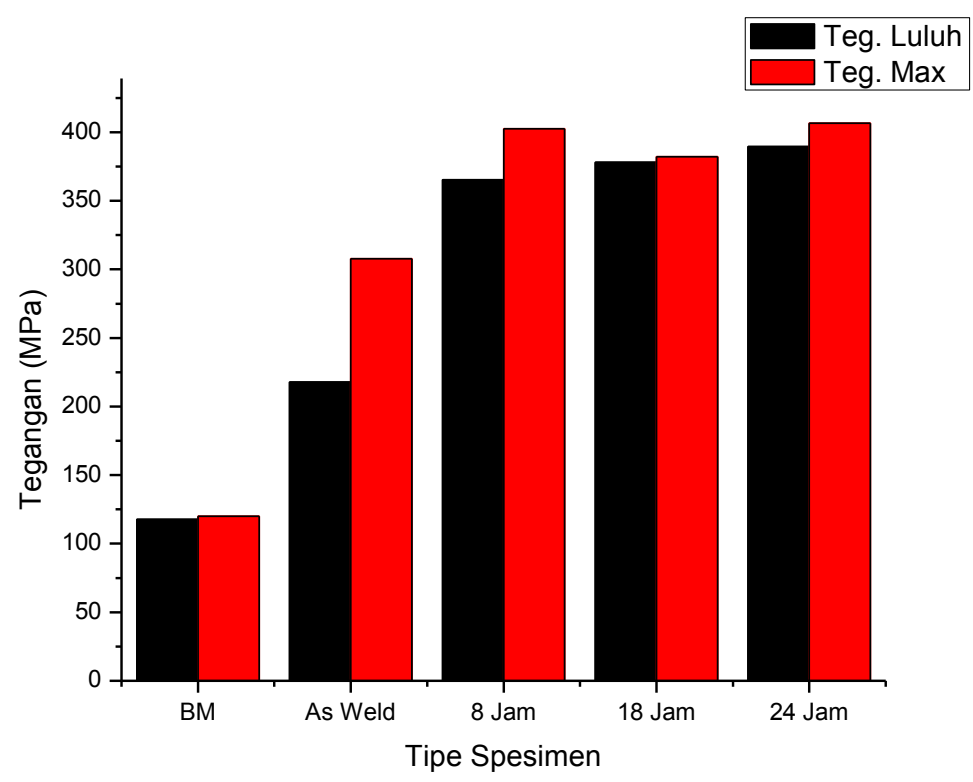

Gambar 5. Grafik kekuatan tarik material pengelasan dan PWHT T6

Pada Gambar 5 menampilkan bahwa logam induk material mempunyai kekuatan luluh 117.647 MPa dan kekuatan tarik maksimum 119.912 MPa, dan spesimen pengelasan tanpa PWHT memiliki kekuatan luluh $217.865 \mathrm{MPa}$ dan kekuatan tarik maksimum $307.850 \mathrm{MPa}$, ini menunjukan bahwa ada peningkatan sebesar $46 \%$ pada nilai kekuatan. Dari tiga spesimen pengelasan yang telah di PWHT, spesimen pengelasan yang di-PWHT selama 8 jam mengahsilkan 
kekuatan luluh 365.294 MPa dan kekuatan tarik maksimum 402.503 MPa.Ini menunjukan bahwa ada peningkatan 40.35\% nilai kekuatan dibanding spesimen pengelasan tanpa PWHT. Pada spesimen pengelasan yang di-PWHT selama 18 jam menghasilkan kekuatan luluh 378.021 MPa dan kekuatan tarik maksimum 382.145 MPa. Ini menunjukan bahwa terjadi peningkatan nilai kekuatan sebesar $42.37 \%$ dibanding spesimen pengelasan tanpa PWHT. Spesimen pengelasan PWHT selama 24 jam menghasilkan nilai kekuatan yang tertinggi yaitu 389.492 MPa dan kekuatan tarik maksimum 406.692 MPa, yaitu 44.06\% lebih tinggi dari spesimen pengelasan tanpa PWHT.

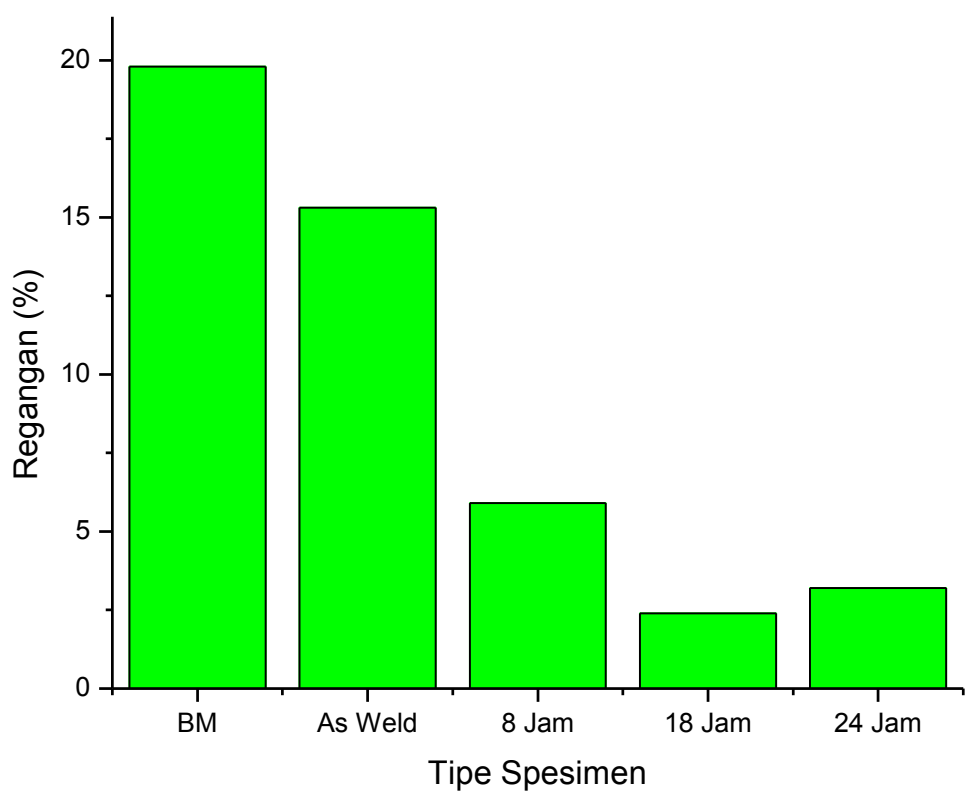

Gambar 6. Grafik regangan material pengelasan dan PWHT T6

Persentase regangan dari logam induk dan logam yang telah di-PWHT dapat dilihat pada Gambar 6.Dapat dilihat pada grafik regangan dari logam induk sebesar $19.8 \%$ dan spesimen pengelasan tanpa PWHT memiliki regangan 15.3\%.Ini menunjukan bahwa ada pengurangan keuletan dari material karena pengaruh pengelasan. Dan material pengelasan dengan PWHT 8 jam, 18 jam dan 24 jam masing-masing memiliki regangan 5.9\%, 2.4\% dan 3.2\%. Dari hasil di atas spesimen pengelasan dengan PWHT 8 jam mempunyai regangan paling tinggi dibandingkan dengan PWHT 18 jam dan 24 jam. Dapat disimpulkan dari hasil pengujian tarik pada aluminium paduan 6061-O pengelasan bahwa PWHT menurunkan keuletan material, tetapi dapat meningkatkan nilai kekuatan tarik. Dari hasil pengujian tarik material tersebut juga didapatkan material PWHT 8 jam mempunyai sifat formability yang paling baik dibanding dengan PWHT 18 dan 24 jam dan nilai kekuatan tariknya juga tidak berbeda jauh dengan PWHT 24 jam yang mempunyai nilai kekutan paling tunggi, dapat dikatakan material PWHT 8 jam merupakan material yang tangguh. Dapat dilihat juga pada material yang tidak mengalami PWHT nilai kekuatan tarik dan regangannya sangat kecil, ini membuktikan masih ada tegangan sisa pada material yang tidak mengalami perlakuan panas [6].

\subsection{Hasil Uji Kekerasan}

Logam dasar ditunjukan pada grafik pada nomor 4-6, daerah HAZ ditunjukan pada nomor 1-3 dan daerah las ditunjukkan pada nomor -2-0.Untuk lebih jelasnya lihat Gambar 7. Dari grafik Gambar 7 kita dapat melihat bahwa nilai kekerasan dari aluminium tanpa PWHT memiliki nilai kekerasan terendah, baik di daerah las, HAZ maupun base metal. Terlihat pada grafik aluminium nilai kekerasan terendah terletak pada base metal yaitu 44,6 HV. Untuk spesimen yang telah mengalami PWHT mengalami kanaikan nilai kekerasan yang signifikan.Dapat dilihat juga nilai kekerasan aluminium yang telah di PWHT mempunyai nilai kekerasan yang hampir seragam.Ini merupakan salah satu alasan mengapa aluminium yang telah di PWHT memiliki kekuatan tarik yang lebih besar daripada aluminium tanpa PWHT. Pada pemanasan selama 18 jam memiliki nilai kekerasan terkecil di pusat las yaitu 79,7 HV. PWHT selama 8 jam memiliki nilai kekerasan yang tertinggi pada pusat las yaitu 108,7 HV. 


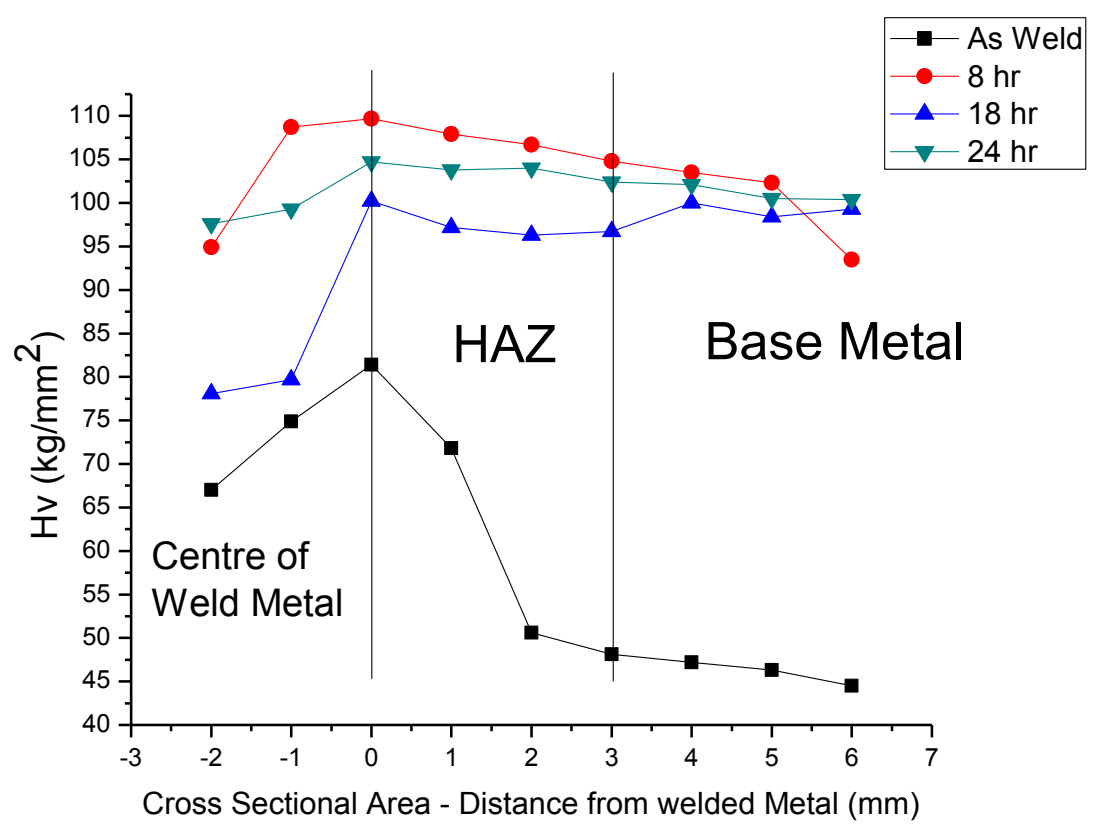

Gambar 7. Distribusi pengujian kekerasan dari daerah pengelasan sampai logam induk

Dari hasil di atas dapat di simpulkan bahwa PWHT sangat berpengaruh terhadap nilai kekerasan material.Nilai kekerasan dari pengelasan longitudinal untuk aging 8 jam adalah yang tertinggi dibandingkan dengan aging 18 jam dan 24 jam.Hal ini terjadi karena pada aging selama 18 dan 24 jam mengalami proses over-aging [7]. Dapat ditarik kesimpulan bahwa proses aging selama 8 jam adalah yang terbaik karena mempunyai nilai kekerasan yang paling baik dibanding aging 18 jam dan 24 jam.

\subsection{Microstructure}

Untuk memperkuat data bahwa hasil pengujian kekerasan dan pengujian tarik itu benar.Maka dilakukan pengujian struktur mikro di Laboratorium Kimia PT. Garuda Maintenance Facility yang bertujuan untuk mengetahui struktur mikronya. Hasil pengujian struktur mikro ditampilakan pada Gambar 8 dengan menggunakan perbesaran 100x. Pengambilan gambar pada pengujian struktur mikro di ambil pada daerah las, HAZ dan logam dasar. Pengujian struktur mikro menggunakan Keller's etching sesuai dengan ASTM E 407.

Hubungan antara mikro struktur dan kekerasan adalah untuk mengidentifikasi presipitasi yang terjadi, sifat mekanik seperti keuletan pada material uji [10].Dari Gambar 8 dapat dilihat struktur mikro dari Al 6061-O pengelasan yang belum di-PWHT dan yang sudah mengalami PWHT selama 8 jam, 18 jam, dan 24 jam pada daerah logam induk, HAZ dan daerah pengelasan yang ditampilkan dalam dua fasa yaitu aluminium solid solution yang ditunjukkan warna abu-abu dan fasa $\mathrm{Mg}_{2} \mathrm{Si}$ yang ditunjukkan dengan warna hitam [9]. Kandungan $\mathrm{Mg}$ dan Si sangat mempengaruhi sifat mekanik dari aluminium jika kedua kandungan tersebut berada pada temperatur yang tepat, campuran ini akan membentuk $\mathrm{Mg}_{2} \mathrm{Si}$ [5].Terlihat pada Gambar 8 terdapat perbedaan pada daerah las, HAZ dan logam induk.

Dapat dilihat pada daerah pengelasan besar ukuran butir seragam pada setiap daerah pengelasan. Pada daerah las tanpa PWHT ukuran rata-rata butir masih sangat besar serta lebih renggang, sedangkan pada material yang mengalami PWHT selama 8 jam, 18 jam dan 24 jam ukuran butir pada daerah pengelasan menjadi lebih kecil daripada daerah las tanpa PWHT, dapat dilihat juga garis hitam yang tampak pada PWHT 8 jam lebih jelas terlihat dibanding dengan PWHT 18 dan 24 jam serta material tanpa PWHT, ini menunjukan bahwa $\mathrm{Mg}_{2} \mathrm{Si}$ paling banyak terbentuk pada PWHT 8 jam, sehingga sangat mempengaruhi sifat mekanik pada material yang mengalami PWHT selama 8 jam [8].

Pada daerah HAZ material tanpa PWHT terlihat ukuran butir lebih besar dibanding dengan HAZ yang mengalami PWHT 8, 18 dan 24 jam. Struktur mikro dari PWHT 8 jam, 18 jam dan 24 jam terlihat pada gambar paling banyak mengandung $\mathrm{Mg}_{2} \mathrm{Si}$. Sehingga pada daerah ini mengalami kenaikan nilai kekerasan yang sangat signifikan.

Daerah logam dasar merupakan daerah yang paling sedikit mengandung $\mathrm{Mg}_{2} \mathrm{Si}$, Namun setelah mendapat PWHT, material tersebut memebentuk $\mathrm{Mg}_{2} \mathrm{Si}$. Dapat dilihat pada Gambar 8 pada logam induk material pengelasan tanpa PWHT sedikit mengandung $\mathrm{Mg}_{2} \mathrm{Si}$ bahkan hampir tidak ada karena pada daerah ini material tidak terpengaruh panas sama sekali. Sementara pada logam induk material PWHT 8 jam terlihat paling banyak menghasilkan $\mathrm{Mg}_{2} \mathrm{Si}$, sehingga dapat dilihat bintik hitam pada gambar lebih banyak dibanding dengan logam dasar PWHT 18 jam dan 24 jam. 


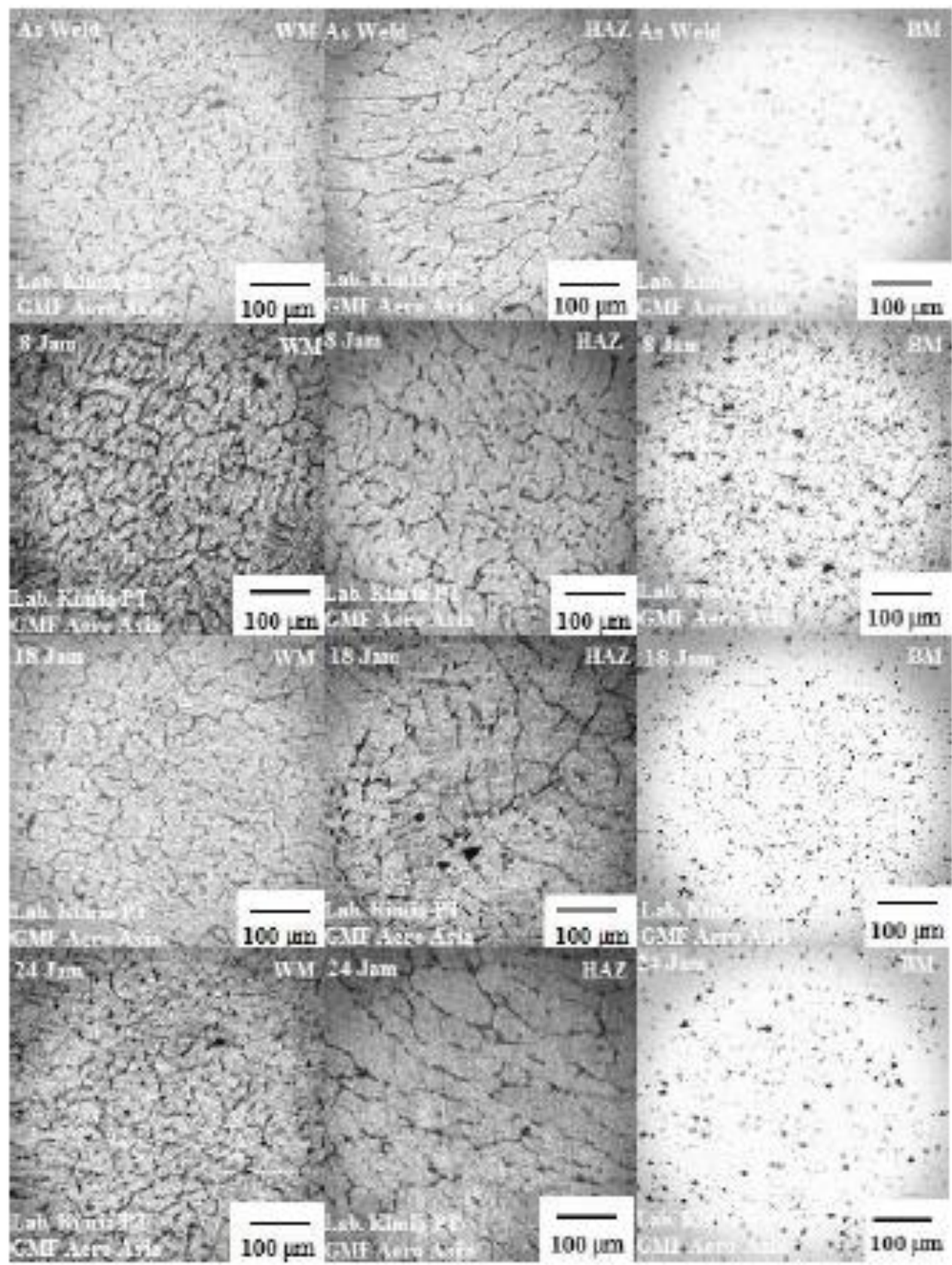

Gambar 8. Struktur mikro dari material pengelasan Al 6061-O dan PWHT T6 perbesaran 100x

\section{KESIMPULAN}

Dari penelitian pengaruh PWHT dan arah pengelasan longitudinal menggunakan las TIG terhadap sifat mekanik dan struktur mikro aluminium 6061-O didapatkan kesimpulan :

1) Dari hasil pengujian tarik material, nilai kekuatan tarik material mengalami peningkatan setelah mengalami proses post weld heat treatment. Nilai kekuatan tarik tertinggi yaitu pada material PWHT selama 24 jam sebesar 389.492 $\mathrm{MPa}$, ini lebih besar dari material PWHT 18 jam sebesar $378.021 \mathrm{MPa}$ dan material PWHT 8 Jam sebesar 365.294 .

2) Dengan melihat hasil pengujian tarik, regangan pada logam induk sebesar $19.8 \%$, material pengelasan tanpa PWHT sebesar 15.3\%, setelah di PWHT 8 jam, 18 jam, dan 24 jam masing-masing memiliki regangan sebesar $5.9 \%, 2.4 \%$, dan $3.2 \%$.

3) Nilai kekerasan cenderung mengalami peningkatan setelah mengalami PWHT. Material pengelasan yang diPWHT 8 jam memiliki nilai kekerasan yang paling tinggi dari material pengelasan tanpa PWHT dan PWHT 18 dan 24 jam. Nilai kekerasan tertinggi ada di daerah HAZ material PWHT 8 jam yaitu sebesar 109.7 Hv. 
4) Dari struktur mikro terlihat adanya perbedaan struktur butir, material tanpa PWHT memiliki ukuran butir yang lebih besar dari material yang diberi perlakuan panas. $\mathrm{Mg}_{2} \mathrm{Si}$ banyak terbentuk pada material yang diberi perlakuan.

5) Dari penelitian ini material yang mempunyai sifat mekanik yang paling baik adalah material pengelasan dengan PWHT selama 8 jam, karena selain mempunyai nilai kekerasan tertinggi, juga memiliki elastisitas yang paling baik dari material PWHT 18 dan 24 jam.

\section{REFERENSI}

[1] Ahmad, R., Bakar, M.A., Effect of a Post-Weld Heat Treatment on the Mechanical and Microstructure Properties of AA6061 Joints Welded by the Gas Metal Arc Welding Cold Metal Transfer Method. J Mater Des 2011; 32: 5120-26

[2] R. Manti, D. K. Dwivedi and A. Agarwal, Pulse TIG welding of two Al-Mg-Si alloys, ASM International, 17 (5) (2008) 667-673

[3] Trudel, Alexandre., Martin, Levesque., Brochu, Myriam. Microstructural effects on the fatigue crack growth resistance of a stainless steel CA6NM weld, Engineering Fracture Mechanics S0013-7944(13)00368-8

[4] M. Temmar, M. Hadji, T. Sahraoui. Effect of post-weld aging treatment on mechanical properties of Tungsten Inert Gas welded low thickness 7075 aluminium alloy joints. Matdes 2011; 32: 3532-6

[5] T.V. Rajan, G.P. Sharma, Ashok Sharma, 1997. Heat treatment principles and techniques, Prentice of India Private Limited.

[6] S. Kou, Welding Metallurgy, Willey Inter-Science, Canada (2003)

[7] Haryadi, Dwi Gunawan., Kim, Seon Jin., Influences of post weld heat treatment on fatigue crack growth behavior of TIG welding of 6013 T4 aluminum alloy joint (Part 1. Fatigue crack growth across the weld metal). J Mech Sci Technol 2011 25(9): 1-10

[8] Y. L. Liu and S. B. Kang, The solidification process of Al-Mg-Si alloys, J. Mater. Sci., 32 (1997) 1443-1447.

[9] Ma T, Den Ouden G. Softening of Al-Zn-Mg aluminium alloys due to welding. JMater Sci Eng A 1999;A 266:198-204

[10] Edwards GA, Stiller K, Dunlop GL, Couper MJ. The precipitation sequence in Al-Mg-Si alloys. Acta Mater 1998; 46: 3893-904 